\title{
LETTER
}

\section{The formation of $\mathrm{CO}_{2}$ by fulvic acid on the surface of goethite studied using ultraviolet and infrared spectroscopy}

\author{
Takahiro OTSUKA and Satoru NAKASHIMA \\ Department of Earth and Space Science, Graduate School of Science, Osaka University, \\ Machikaneyama-cho, Toyonaka, Osaka 560-0043, Japan
}

\begin{abstract}
Changes in the absorption intensity (absorbance) at $254 \mathrm{~nm}$ of a fulvic acid solution in the presence of goethite powder were monitored in situ in a liquid cell at a temperature of $80^{\circ} \mathrm{C}$ in a UV-visible spectrometer. The absorbance at $254 \mathrm{~nm}$ decreased rapidly with time in the initial stage in the presence of goethite with a first-order rate constant of $k_{1}^{\mathrm{UV}}=3 \times 10^{-4} \mathrm{~s}^{-1}$, while in the absence of goethite, the absorbance at $254 \mathrm{~nm}$ decreased slowly with time, with a first-order rate constant of $k_{0}^{\mathrm{UV}}=6 \times 10^{-7} \mathrm{~s}^{-1}$. A hydrothermal vessel was connected to a longpath gas cell infrared spectrometer to monitor the volatile compounds formed on heating the fulvic acid at 80 ${ }^{\circ} \mathrm{C}$. Carbon dioxide formed gradually over time from the fulvic acid solution in the absence of goethite $\left(k_{0}^{\mathrm{CO}_{2}}=\right.$ $\left.1.5 \times 10^{-6} \mathrm{~s}^{-1}\right)$. The formation of $\mathrm{CO}_{2}$ in the presence of goethite occurred via two first-order reactions. The initial first-order rate constant of $\mathrm{CO}_{2}$ formation from fulvic acid in the presence of goethite $\left(k_{1}^{\mathrm{CO}_{2}}=3.2 \times 10^{-4} \mathrm{~s}^{-1}\right)$ had the same magnitude as the decrease in absorbance at $254 \mathrm{~nm}$. The second rate constant of $\mathrm{CO}_{2}$ formation $\left(k_{2}^{\mathrm{CO}_{2}}=1.8 \times 10^{-6} \mathrm{~s}^{-1}\right)$ had the same magnitude as $\mathrm{CO}_{2}$ formation in the absence of goethite. These results suggest that the formation of $\mathrm{CO}_{2}$ from the fulvic acid is greatly accelerated by the presence of goethite, possibly through the adsorption of the fulvic acid on the goethite surface with subsequent redox reactions occurring.
\end{abstract}

Keywords: $\mathrm{CO}_{2}$ formation, Organic-inorganic reaction, Fulvic acid, Goethite

\section{INTRODUCTION}

Organic compounds are supposed to be decomposed and finally oxidized to $\mathrm{CO}_{2}$ on geological surfaces as $\mathrm{CH}_{2} \mathrm{O}+$ $\mathrm{O}_{2} \rightarrow \mathrm{CO}_{2}+\mathrm{H}_{2} \mathrm{O}$ (Berner, 1980). On the other hand, various interactions of organic matter with minerals are commonly observed on the Earth's surface (Stumm and Morgan, 1996; Blesa et al., 2000). Recently, enhanced $\mathrm{CO}_{2}$ formation from organic matter was found on oxide minerals (Majcher et al., 2000; Wang and Huang, 2000). However, the mechanism and rate of $\mathrm{CO}_{2}$ formation on oxide minerals are not known.

Common dissolved organic compounds existing in the environment, such as fulvic acid, have been reported to be adsorbed on oxide minerals, such as goethite ( $\mathrm{Gu}$ et al., 1994; Filius et al., 2000; Zhou et al., 2001). The ferric iron in iron hydroxides is often reduced to ferrous iron in the presence of organic matter (LaKind and Stone, 1989; Chorover and Amistadi, 2001; Pullin and Cabaniss, 2003). Although organic compounds are supposed to be oxidized in turn, and have the capability to form $\mathrm{CO}_{2}$, the

doi: $10.2465 /$ jmps.070619c

T. Otsuka, totsuka@ess.sci.osaka-u.ac.jp Corresponding author

S. Nakashima, satoru@ess.sci.osaka-u.ac.jp details of these redox reactions are not yet understood. To investigate the possible formation of $\mathrm{CO}_{2}$ from organic matter in the presence of iron hydroxides, in this study, we carried interaction experiments between a representative dissolved organic compound, fulvic acid, and a representative iron hydroxide, goethite. The interaction experiments were conducted at $80{ }^{\circ} \mathrm{C}$ to accelerate the reactions. The decrease in fulvic acid in solution was monitored in situ using ultraviolet-visible (UV-Vis) spectroscopy by measuring the absorption intensity at $254 \mathrm{~nm}$, which is commonly used as a measure of dissolved organic carbon content (Korshin et al., 1997). Long-path gas cell infrared (IR) spectroscopy (Ishikawa et al., 2007) was employed to quantify the gaseous products produced, including $\mathrm{CO}_{2}$, from the fulvic acid. Using these spectroscopic methods, the reaction kinetics of fulvic acid in the presence of goethite was investigated.

\section{MATERIALS AND METHODS}

\section{Goethite and fulvic acid solution}

The goethite samples were prepared using the method of Schwertmann and Cornell (2000). Iron hydroxide was 
precipitated in a polyethylene vessel by adding $180 \mathrm{~mL}$ of a $5 \mathrm{M}$ potassium hydroxide solution to $100 \mathrm{~mL}$ of a $0.1 \mathrm{M}$ $\mathrm{Fe}\left(\mathrm{NO}_{3}\right)_{3}$ solution. The suspension was immediately diluted to a volume of $2 \mathrm{~L}$ using pure water (MilliQ-UV), and incubated at $70{ }^{\circ} \mathrm{C}$ for a period of $60 \mathrm{~h}$. The yellowish-brown precipitate obtained was centrifuged and then washed. The product was identified as goethite using $\mathrm{X}^{-}$ ray diffraction and FT-IR spectroscopy (Nagano et al., 1992).

A fulvic acid standard, Nordic aquatic fulvic acid powder, was obtained from the International Humic Substances Society (IHSS), with an elemental composition of: $\mathrm{C}=52.3, \mathrm{H}=4.0, \mathrm{O}=45.1$, and $\mathrm{N}=0.7 \mathrm{wt} \%$. The functional group content was: $\mathrm{COOH}=11.2 \mathrm{mmol} / \mathrm{gC}$ (13.4 wt\% of the carbon was in the form of $\mathrm{COOH}$ ) and $\mathrm{OH}=3.2 \mathrm{mmol} / \mathrm{gC}$ (Ritchie and Perdue, 2003). Stock solutions containing 200 and $500 \mathrm{mg} / \mathrm{L}$ of Nordic fulvic acid were prepared using pure water. The $\mathrm{pH}$ of these solutions was adjusted to $\mathrm{pH}=4$ using $0.01 \mathrm{M} \mathrm{HCl}$ and 0.01 $\mathrm{M} \mathrm{NaOH}$ solutions.

\section{Batch hydrothermal experiments}

A steel-lined PTFE (Teflon) reaction vessel was connected to a long-path gas cell (10-m path length) placed in a Bomem MB154 Fourier transform infrared (FT-IR) spectrometer (Fig. 1). Reflecting IR mirrors were set at both ends of the $25^{-} \mathrm{cm}$ long cell to obtain a 40 times reflection, yielding a full $10 \mathrm{~m}$ optical path length. A $20 \mathrm{~mL}$ plastic syringe was used to introduce the sample solutions and for the sampling products (Fig. 1). A vacuum pump and a $\mathrm{N}_{2}$ gas bombe ( $99.9999 \%$ purity) were connected to the lines to obtain a non-oxidizing atmosphere throughout the entire system.

A volume of $15 \mathrm{~mL}$ of a $200 \mathrm{mg} / \mathrm{L}$ fulvic acid solution and a volume of $15 \mathrm{~mL}$ of a $20 \mathrm{~g} / \mathrm{L}$ goethite suspension were purged with $99.9999 \%$ nitrogen gas in advance. The fulvic acid solution was then added to the goethite suspension in the hydrothermal reaction system described above under a nitrogen atmosphere.

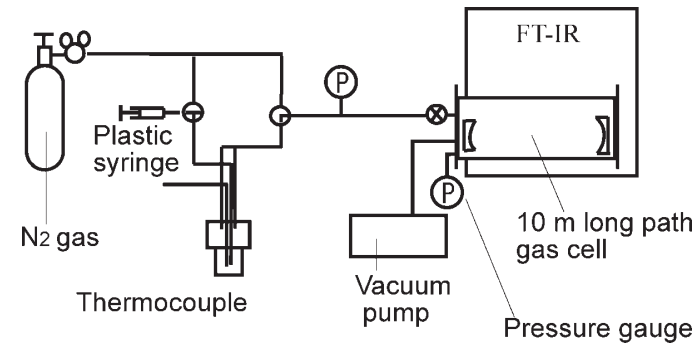

Figure 1. The $10-\mathrm{m}$ long path gas cell Bomem MB154 FT-IR spectrometer connected to the steel-lined PTFE (Teflon) hydrothermal reaction vessel.
The hydrothermal experiments were conducted at a temperature of $80{ }^{\circ} \mathrm{C}$ for periods of 0 and $24 \mathrm{~h}$ in the absence of goethite, and for periods of $0,2,4,6,9,12,18$, and $24 \mathrm{~h}$ in the presence of goethite. The product solutions were filtered using a $0.45^{-} \mu \mathrm{m} \mathrm{MF-membrane}{ }^{\mathrm{TM}}$ filter. The UV-Vis spectra of the filtered solutions were obtained using a Jasco V-570 UV-Vis spectrophotometer using $1.0 \mathrm{~cm}$ quartz cells. The gaseous products formed during the hydrothermal reactions were introduced by the nitrogen gas to the long-path gas cell FT-IR (Fig. 1) to measure their IR spectra.

\section{In situ hydrothermal experiments}

In situ hydrothermal experiments were conducted at 80 ${ }^{\circ} \mathrm{C}$ for periods of 0 to $24 \mathrm{~h}$ in the presence / absence of goethite using a heatable liquid cell set in a Jasco V-530 UV-Vis spectrophotometer. A mass of $1.25 \mathrm{mg}$ of goethite powder was added to a volume of $25 \mu \mathrm{L}$ of the $500 \mathrm{mg} / \mathrm{L}$ fulvic acid solution in the heatable liquid cell. The UVVis spectra of the mixture were measured every $2 \mathrm{~min}$ while maintaining the solution at $80{ }^{\circ} \mathrm{C}$. The weight ratio of goethite to fulvic acid was set to a value of $(100: 1)$ for the batch and in situ hydrothermal experiments.

\section{RESULTS AND DISCUSSION}

\section{Decrease rate of absorbance at $254 \mathrm{~nm}$ by fulvic acid in the presence / absence of goethite}

The UV-Vis spectra of the product solutions at $80{ }^{\circ} \mathrm{C}$ for periods of 0 and $24 \mathrm{~h}$ in the absence of goethite did not

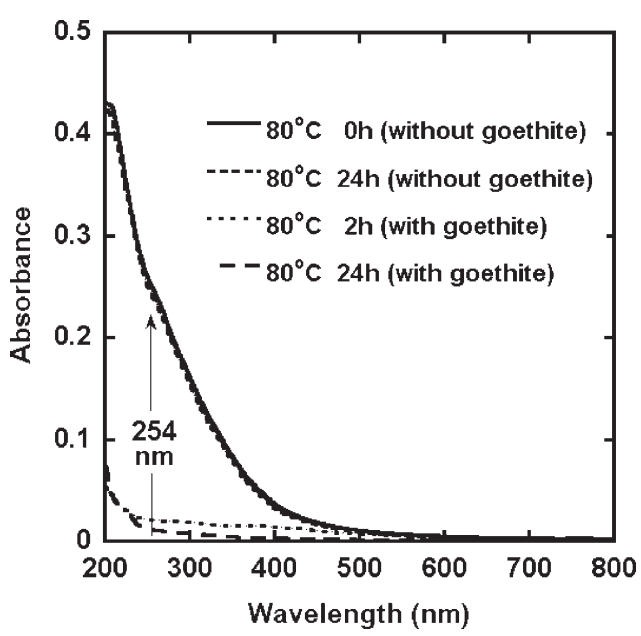

Figure 2. Ultraviolet-visible spectra obtained from the product solutions at $80{ }^{\circ} \mathrm{C}$ for periods of 0 and $24 \mathrm{~h}$ in the absence of goethite, and for periods of 2 and $24 \mathrm{~h}$ in the presence of goethite, taken using the batch hydrothermal experimental apparatus shown in Figure 1. 


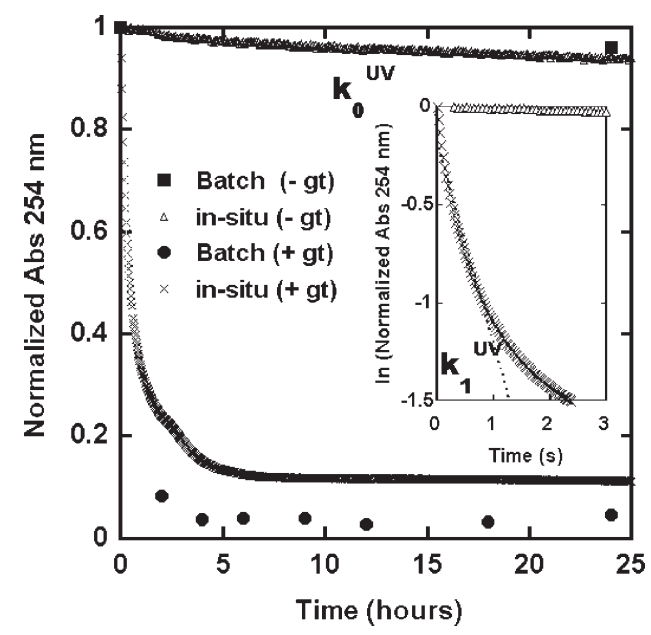

Figure 3. Change in the absorbance at $254 \mathrm{~nm}$ with time at $80{ }^{\circ} \mathrm{C}$ in the presence / absence of goethite during the batch and in situ hydrothermal experiments. The value of the absorbance at 254 $\mathrm{nm}$ was normalized by the initial value. The in situ data in the initial stage up to a period of $3 \mathrm{~h}$ are shown in the inset as a semi-logarithm plot. Consult the main text for the curve fitting information used to obtain the first-order rate constants of $k_{0}^{\mathrm{UV}}=$ $6 \times 10^{-7} \mathrm{~s}^{-1}$ and $k_{1}^{\mathrm{UV}}=3 \times 10^{-4} \mathrm{~s}^{-1}$.

show any significant difference from that of the initial Nordic fulvic acid solution (Fig. 2). On the other hand, the spectra in the presence of goethite showed a marked decrease in their absorbance within a period of $2 \mathrm{~h}$. The absorption intensity (absorbance) at $254 \mathrm{~nm}$ of the fulvic acid solution is due to the $\pi^{-} \pi^{*}$ electron transfer originating from substituted aromatic structures, and is commonly used as a measure of dissolved organic matter content (Korshin et al., 1997). Therefore, the absorbance values at $254 \mathrm{~nm}$ of the product solutions are plotted versus time in Figure 3. In the absence of goethite, the absorbance at $254 \mathrm{~nm}$ showed only a slight decrease on heating at $80{ }^{\circ} \mathrm{C}$ for a period of $24 \mathrm{~h}$, while it decreased to a value of about 0.1 of the initial value within a period of $2 \mathrm{~h}$, and then remained mostly unchanged around a value of 0.05 in the presence of goethite.

In situ UV-Vis experiments were conducted to study the rapid changes in the absorbance at $254 \mathrm{~nm}$. The in situ data for the absorbance at $254 \mathrm{~nm}$ showed a slow decrease at $80{ }^{\circ} \mathrm{C}$ in the absence of goethite (Fig. 3). The batch data for a period of $24 \mathrm{~h}$ in the absence of goethite closely followed this trend. On the other hand, the in situ data at $80{ }^{\circ} \mathrm{C}$ in the presence of goethite appeared to decrease very rapidly (Fig. 3). The batch data in the presence of goethite were about 0.1 lower than the in situ data. This difference may be due to light scattering and absorption by the goethite particles in the in situ experiments and from the loss of adsorbed fulvic acid on the goethite during filtering in the batch experiment.

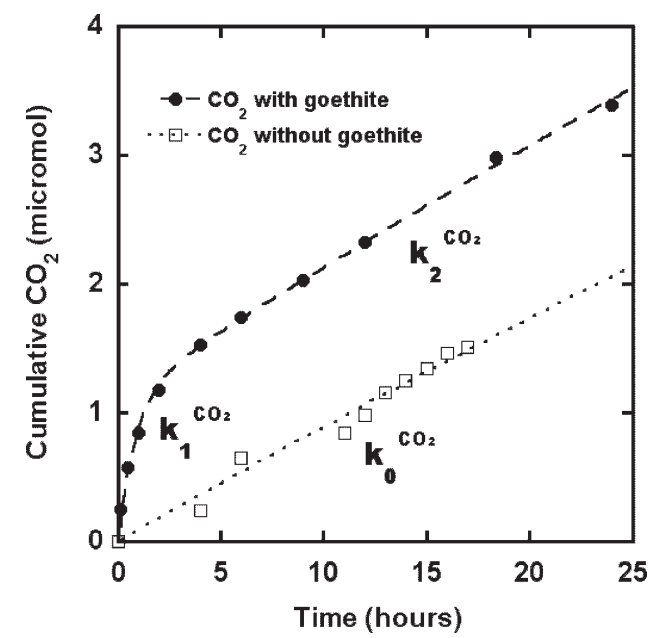

Figure 4. The cumulative formation of $\mathrm{CO}_{2}$ with time from fulvic acid at $80{ }^{\circ} \mathrm{C}$ in the presence / absence of goethite during the batch hydrothermal experiments. Consult the main text for the curve fitting information used to obtain the first-order rate constants of $k_{0}^{\mathrm{CO}_{2}}=1.5 \times 10^{-6} \mathrm{~s}^{-1}, k_{1}^{\mathrm{CO}_{2}}=3.2 \times 10^{-4} \mathrm{~s}^{-1}$, and $k_{2}^{\mathrm{CO}_{2}}=1.8$ $\times 10^{-6} \mathrm{~s}^{-1}$.

The slow decrease in absorbance at $254 \mathrm{~nm}$ of the fulvic acid in the absence of goethite can be used to determine the first-order reaction rate constant $\left(k_{0}^{\mathrm{UV}}=6 \times\right.$ $10^{-7} \mathrm{~s}^{-1}$ ) by fitting the data until a period of $24 \mathrm{~h}$ using an exponential curve. The absorbance at $254 \mathrm{~nm}$ decreased in the presence of goethite rapidly during the initial stage, but became slower at a later stage, reaching a constant value, indicating the contribution of several processes. These processes can be modeled, for example, by the sum of two independent first-order reactions, or three successive first-order reactions. Our simulations gave a rate constant for the initial stage, $k_{1}^{\mathrm{UV}}$, of between $2 \times 10^{-4} \mathrm{~s}^{-1}$ and $5 \times 10^{-4} \mathrm{~s}^{-1}$. Alternatively, the data in the period up to $1 \mathrm{~h}$, which showed a quasi-linear trend in a semi-logarithmic plot (insert in Fig. 3), can be fitted using an exponential curve to obtain the apparent first-order reaction rate constant of $k_{1}^{\mathrm{UV}}=3 \times 10^{-4} \mathrm{~s}^{-1}$. Since this value is of the same order as the above complex simulation, and a precise kinetic treatment will need further experimental data, we used this initial stage first-order rate constant in our study. The rapid decrease in fulvic acid from solution suggests it was adsorbed on the goethite.

\section{Rate of formation of $\mathrm{CO}_{2}$ from fulvic acid in the pres- ence / absence of goethite}

The gaseous products formed in the batch hydrothermal experiments and analyzed using gas cell FT-IR spectroscopy indicated that only $\mathrm{CO}_{2}$ was formed as a recognizable species. Carbon monoxide and other incomplete combustion gases were not detected. In the absence of 
goethite, the cumulative amount of $\mathrm{CO}_{2}$ formed gradually increased with time (Fig. 4). By assuming that the maximum formation of $\mathrm{CO}_{2}$ was limited by the initial carboxylic group content of the fulvic acid, $C_{0}=1.75 \times 10^{-5} \mathrm{~mol}$ for $3 \mathrm{mg}$ of fulvic acid, then the rate of formation of $\mathrm{CO}_{2}$ can be modeled using the first-order kinetics by assuming this value of $C_{0}$ \{where $\left.C=C_{0}\left[1-\exp \left(k_{0}^{\mathrm{CO}_{2}} t\right)\right]\right\}$. The calculated first-order rate of formation of $\mathrm{CO}_{2}$ was $k_{0}^{\mathrm{CO}_{2}}=1.5$ $\times 10^{-6} \mathrm{~s}^{-1}$.

On the other hand, the $\mathrm{CO}_{2}$ formed in the presence of goethite showed a rapid increase in the initial stage, and then the release of $\mathrm{CO}_{2}$ increased gradually with time (Fig. 4). Assuming that the $\mathrm{CO}_{2}$ was formed by two independent first-order reactions $\left\{C=C_{1}\left[1-\exp \left(k_{1}^{\mathrm{CO}_{2}} t\right)\right]+\left(C_{0}\right.\right.$ $\left.\left.-C_{1}\right)\left[1-\exp \left(k_{2}^{\mathrm{CO}_{2}} t\right)\right]\right\}$, then the first-order rate of formation of $\mathrm{CO}_{2}$ can be obtained by fitting the data up to a period of $24 \mathrm{~h}$ using the above equation (Fig. 4) $\left(k_{1}^{\mathrm{CO}_{2}}=3.2 \times\right.$ $10^{-4} \mathrm{~s}^{-1}$ and $k_{2}^{\mathrm{CO}_{2}}=1.8 \times 10^{-6} \mathrm{~s}^{-1}$ for $\left.C_{1}=1.1 \times 10^{-6} \mathrm{~mol}\right)$. The amount of $\mathrm{CO}_{2}$ formed in the presence of goethite, $C_{1}$, comprises only about $6 \%$ of the initial carboxyl content, $C_{0}$.

The first-order rate of formation of $\mathrm{CO}_{2}$ from fulvic acid in the presence of goethite $\left(k_{1}^{\mathrm{CO}_{2}}=3.2 \times 10^{-4} \mathrm{~s}^{-1}\right)$ is of the same order as the above initial first-order rate in the decrease in absorbance at $254 \mathrm{~nm}\left(k_{1}^{\mathrm{UV}}=3 \times 10^{-4} \mathrm{~s}^{-1}\right)$. This indicates that the mechanism of formation of $\mathrm{CO}_{2}$ may be related to the adsorption of fulvic acid on the goethite. The first- ${ }^{-}$order rate of formation of $\mathrm{CO}_{2}$ in the presence of goethite in the second stage $\left(k_{2}^{\mathrm{CO}_{2}}=1.8 \times 10^{-6} \mathrm{~s}^{-1}\right)$ agrees with the rate in the absence of goethite $\left(k_{0}^{\mathrm{CO}_{2}}=1.5\right.$ $\left.\times 10^{-6} \mathrm{~s}^{-1}\right)$.

These results suggest that the hydrothermal transformation of fulvic acid to produce $\mathrm{CO}_{2}$ is greatly accelerated by the presence of goethite, possibly through the adsorption of the fulvic acid on the goethite surface followed by subsequent redox reactions. Further studies are needed to clarify the mechanism of the surface interaction of fulvic acid with goethite.

\section{REFERENCES}

Berner, R.A. (1980) Early diagenesis a theoretical approach, pp. 241, Princeton University Press, Princeton.

Blesa, M.A., Weisz, A.D., Morando, P.J., Salfity, J.A., Magaz, G.E. and Regazzoni, A.E. (2000) The interaction of metal oxide surfaces with complexing agents dissolved in water. Coordination Chemistry Reviews, 196, 31-63.
Chorover, J. and Amistadi, M.K. (2001) Reaction of forest floor organic matter at goethite, birnessite and smectite surfaces. Geochimica et Cosmochimica Acta, 65, 95-109.

Filius, J.D., Lumsdon, D.G., Meeussen, J.C.L., Hiemstra, T. and van Riemsduk, W.H. (2000). Adsorption of fulvic acid on goethite. Geochimica et Cosmochimica Acta, 64, 51-60.

Gu, B., Schmitt, J., Chen, Z., Liang, L. and McCathy, J.F. (1994) Adsorption and Desorption of natural organic matter on iron oxide: mechanisms and models. Environmental Science and Technology, 28, 38-46.

Ishikawa, K., Tani, A., Otsuka, T. and Nakashima, S. (2007) Transformation of $\gamma$-ray-formed methyl radicals in methane hydrate at 10MPa. Japanese Journal of Applied Physics, 46, 455-460.

Korshin, G.V., Li, C. and Benjamin, M.M. (1997) Monitoring the properties of natural organic matter through UV spectroscopy: a consistent theory. Water Research, 31, 1787-1795.

LaKind, J.S. and Stone, A.T. (1989) Reductive dissolution of goethite by phenolic reductants. Geochimica et Cosmochimica Acta, 53, 961-971.

Majecher, E.M., Chorover, J., Bollag, J-M. and Huang, P.M. (2000) Evolution of $\mathrm{CO}_{2}$ during the birnessite-induced oxidation of ${ }^{14} \mathrm{C}$-labeled catechol. Soil Science Society of America Journal, 64, 157-163.

Nagano, T., Nakashima, S., Nakayama, S., Osada, K. and Senoo, M. (1992) Color variations associated with rapid formation of goethite from proto-ferrihydrite at $\mathrm{pH} 13$ and $40{ }^{\circ} \mathrm{C}$. Clays and Clay Minerals, 40, 600-607.

Pullin, M.J. and Cabaniss, S.E. (2003) The effect of pH, ionic strength, and iron-fulvic acid interactions on the kinetics of non photochemical iron transformations. II. The kinetics of thermal reduction. Geochimica et Cosmochimica Acta, 67, 4079-4089.

Ritchie, J.D. and Perdue, E.M. (2003) Proton-binding study of standard and reference fulvic acids, humic acids, and natural organic matter. Geochimica et Cosmochimica Acta, 67, 85-96.

Schwertmann, U. and Cornell, R.M. (2000) Iron oxides in the laboratory: preparation and characterization $\left(2^{\text {nd }}\right.$ ed.). $p p$. 188, Wiley-VCH, New York.

Stumm, W. and Morgan, J.J. (1996) Aquatic chemistry: chemical equilibria and rates in natural waters $\left(3^{\text {rd }}\right.$ ed.). pp. 1022 , Willey, New York.

Wang, M.C. and Huang, P.M. (2000) Ring cleavage and oxidative transformation of pyrogallol catalyzed by $\mathrm{Mn}, \mathrm{Fe}, \mathrm{Al}$, and $\mathrm{Si}$ oxides, Soil Science, 165, 934-942.

Zhou, Q. Maurice, P.A. and Cabaniss, S.E. (2001) Size fractionation upon adsorption of fulvic acid on goethite: equilibrium and kinetic studies, Geochimica et Cosmochimica Acta, 65, 803-812.

Manuscript received June 19, 2007

Manuscript accepted August 27, 2007

Manuscript handled by Koichiro Fujimoto 